\title{
Rhodium-Catalyzed Kinetic Resolution of Tertiary Homoallyl Alcohols via Stereoselective Carbon-Carbon Bond Cleavage
}

\author{
Ryo Shintani,* Keishi Takatsu, and Tamio Hayashi* \\ Department of Chemistry, Graduate School of Science, Kyoto University, \\ Sakyo, Kyoto 606-8502, Japan
}

\section{Supporting Information}

\section{General}

All air- and moisture-sensitive manipulations were carried out with standard Schlenk techniques under nitrogen or in a glove box under argon.

$\mathrm{Et}_{2} \mathrm{O}, \mathrm{THF}$, and toluene were purified by passing through a neutral alumina column under nitrogen.

Allyl bromide (TCI), acetophenone (Wako Chemicals), 2-acetonaphthone (TCI), 1acetonaphthone (Wako Chemicals), pinacolone (Wako Chemicals), 1-tetralone (Wako Chemicals), (E)-2-pentenal (Aldrich), (+)-neomenthyldiphenylphosphine (Aldrich), phenyllithium (Kanto Chemicals; $1.08 \mathrm{M}$ solution in cyclohexane/ $\mathrm{Et}_{2} \mathrm{O}$ ), iodine (Nacalai Tesque), magnesium turnings (Wako Chemicals), and $\mathrm{MnO}_{2}$ (Wako Chemicals) were used as received. 4-Methoxybenzyl-2,2,2-trichloroethanimidate, ${ }^{1}[\mathrm{Rh}(\mathrm{OH})(\mathrm{cod})]_{2},{ }^{2}(R)$-MeO-mop, ${ }^{3}$ $(S)-(R)$-ppfa, ${ }^{4}(R)$-binap, ${ }^{5}(R)$-segphos ${ }^{6}$, and $(R)-\mathrm{H}_{8}$-binap ${ }^{7}$ were synthesized following the literature procedures.

\section{Synthesis of Substrates}

The yields have not been optimized.

\section{Preparation of Allylmagnesium Bromide}

A flake of iodine was added to a suspension of magnesium turings $(2.67 \mathrm{~g}, 110 \mathrm{mmol})$ in $\mathrm{Et}_{2} \mathrm{O}(20 \mathrm{~mL})$ and the mixture was stirred until the color of iodine disappeared. A solution of

\footnotetext{
${ }^{1}$ Bourgeois, D.; Craig, D.; Grellepois, F.; Mountford, D. M.; Stewart, A. J. W. Tetrahedron 2006, 62, 483.

${ }^{2}$ Uson, R.; Oro, L. A.; Cabeza, J. A. Inorg. Synth. 1985, 23, 126.

${ }^{3}$ Uozumi, Y.; Tanahashi, A.; Lee, S.-Y.; Hayashi, T. J. Org. Chem. 1993, 58, 1945.

${ }^{4}$ Hayashi, T.; Mise, T.; Fukushima, M.; Kagotani, M.; Nagashima, N.; Hamada, Y.; Matsumoto, A.; Kawakami, S.; Konishi, M.; Yamamoto, K.; Kumada, M. Bull. Chem. Soc. Jpn. 1980, 53, 1138.

${ }^{5}$ Cai, D.; Payack, J. F.; Bender, D. R.; Hughes, D. L.; Verhoeven, T. R.; Reider, P. J. J. Org. Chem. 1994, 59, 7180.

${ }^{6}$ Saito, T.; Yokozawa, T.; Ishizaki, T.; Moroi, T.; Sayo, N.; Miura, T.; Kumobayashi, H. Adv. Synth. Catal. 2001, 343, 264.

${ }^{7}$ Zhang, X.; Sayo, N. Eur. Pat. Appl. 1998, EP0839819.
} 
allyl bromide $(4.33 \mathrm{~mL}, 50.0 \mathrm{mmol})$ in $\mathrm{Et}_{2} \mathrm{O}(40 \mathrm{~mL})$ was added dropwise to it at $0{ }^{\circ} \mathrm{C}$ over $1.5 \mathrm{~h}$. The resulting mixture was stirred for additional $30 \mathrm{~min}$ at $0{ }^{\circ} \mathrm{C}$ and warmed to room temperature. The concentration was determined to be $0.65 \mathrm{M}$ by acid-base titration with methyl orange.

\section{2-Phenyl-4-penten-2-ol (1a) (CAS 4743-74-2)}

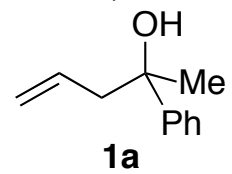

Allylmagnesium bromide $\left(9.5 \mathrm{~mL}, 6.2 \mathrm{mmol} ; 0.65 \mathrm{M}\right.$ solution in $\left.\mathrm{Et}_{2} \mathrm{O}\right)$ was added to a solution of acetophenone $(482 \mathrm{mg}, 4.01 \mathrm{mmol})$ in THF $(8.0 \mathrm{~mL})$ at $0{ }^{\circ} \mathrm{C}$ and the mixture was stirred for $1 \mathrm{~h}$ at room temperature. The mixture was quenched with saturated $\mathrm{NH}_{4} \mathrm{Claq}$ and extracted with $\mathrm{Et}_{2} \mathrm{O}$. The organic layer was dried over $\mathrm{MgSO}_{4}$, filterd, and concentrated under vacuum. The residue was chromatographed on silica gel with EtOAc/hexane $=1 / 12$ to afford 1a as a colorless oil (455 $\mathrm{mg}, 2.81 \mathrm{mmol} ; 70 \%$ yield).

${ }^{1} \mathrm{H} \mathrm{NMR}\left(\mathrm{CDCl}_{3}\right): \delta 7.43\left(\mathrm{~d},{ }^{3} J_{\mathrm{HH}}=7.5 \mathrm{~Hz}, 2 \mathrm{H}\right), 7.33\left(\mathrm{t},{ }^{3} J_{\mathrm{HH}}=7.6 \mathrm{~Hz}, 2 \mathrm{H}\right), 7.23\left(\mathrm{t},{ }^{3} J_{\mathrm{HH}}\right.$ $=7.3 \mathrm{~Hz}, 1 \mathrm{H}), 5.62\left(\mathrm{dddd},{ }^{3} J_{\mathrm{HH}}=16.8,10.1,8.3\right.$, and $\left.6.6 \mathrm{~Hz}, 1 \mathrm{H}\right), 5.12\left(\mathrm{~d},{ }^{3} J_{\mathrm{HH}}=16.0 \mathrm{~Hz}\right.$, $1 \mathrm{H}), 5.11\left(\mathrm{~d},{ }^{3} J_{\mathrm{HH}}=10.0 \mathrm{~Hz}, 1 \mathrm{H}\right), 2.68\left(\mathrm{dd},{ }^{2} J_{\mathrm{HH}}=13.7 \mathrm{~Hz}\right.$ and $\left.{ }^{3} J_{\mathrm{HH}}=6.4 \mathrm{~Hz}, 1 \mathrm{H}\right), 2.50(\mathrm{dd}$, ${ }^{2} J_{\mathrm{HH}}=13.7 \mathrm{~Hz}$ and $\left.{ }^{3} J_{\mathrm{HH}}=8.3 \mathrm{~Hz}, 1 \mathrm{H}\right), 2.09(\mathrm{~s}, 1 \mathrm{H}), 1.54(\mathrm{~s}, 3 \mathrm{H}) .{ }^{13} \mathrm{C} \mathrm{NMR}\left(\mathrm{CDCl}_{3}\right): \delta$ $147.8,133.8,128.3,126.7,124.9,119.5,73.7,48.6,30.0$.

\section{2-(2-Naphthyl)-4-penten-2-ol (1b) (CAS 81336-07-4)}

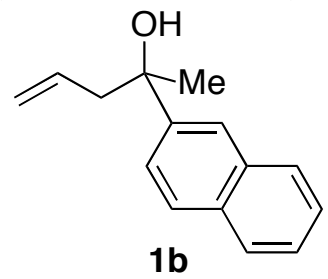

Allylmagnesium bromide $\left(6.5 \mathrm{~mL}, 4.2 \mathrm{mmol} ; 0.65 \mathrm{M}\right.$ solution in $\left.\mathrm{Et}_{2} \mathrm{O}\right)$ was added to a solution of 2-acetonaphthone $(345 \mathrm{mg}, 2.03 \mathrm{mmol})$ in $\mathrm{THF}(8.0 \mathrm{~mL})$ at $0{ }^{\circ} \mathrm{C}$ and the mixture was stirred for $2.5 \mathrm{~h}$ at room temperature. The mixture was quenched with saturated $\mathrm{NH}_{4} \mathrm{Claq}$ and extracted with $\mathrm{Et}_{2} \mathrm{O}$. The organic layer was dried over $\mathrm{MgSO}_{4}$, filterd, and concentrated under vacuum. The residue was chromatographed on silica gel with EtOAc/hexane $=1 / 10$ to afford $\mathbf{1 b}$ as a colorless oil (423 $\mathrm{mg}, 1.99 \mathrm{mmol}$; 98\% yield).

${ }^{1} \mathrm{H} \mathrm{NMR}\left(\mathrm{CDCl}_{3}\right): \delta 7.96(\mathrm{~s}, 1 \mathrm{H}), 7.88-7.84(\mathrm{~m}, 3 \mathrm{H}), 7.58\left(\mathrm{dd},{ }^{3} J_{\mathrm{HH}}=8.6 \mathrm{~Hz}\right.$ and ${ }^{4} J_{\mathrm{HH}}=$ $1.9 \mathrm{~Hz}, 1 \mathrm{H}), 7.53-7.47(\mathrm{~m}, 2 \mathrm{H}), 5.67\left(\mathrm{dddd},{ }^{3} J_{\mathrm{HH}}=16.7,10.1,8.3\right.$, and $\left.6.4 \mathrm{~Hz}, 1 \mathrm{H}\right), 5.19(\mathrm{~d}$, $\left.{ }^{3} J_{\mathrm{HH}}=16.5 \mathrm{~Hz}, 1 \mathrm{H}\right), 5.15\left(\mathrm{~d},{ }^{3} J_{\mathrm{HH}}=10.1 \mathrm{~Hz}, 1 \mathrm{H}\right), 2.83\left(\mathrm{dd},{ }^{2} J_{\mathrm{HH}}=13.8 \mathrm{~Hz}\right.$ and ${ }^{3} J_{\mathrm{HH}}=6.4$ $\mathrm{Hz}, 1 \mathrm{H}), 2.63\left(\mathrm{dd},{ }^{2} J_{\mathrm{HH}}=13.8 \mathrm{~Hz}\right.$ and $\left.{ }^{3} J_{\mathrm{HH}}=8.4 \mathrm{~Hz}, 1 \mathrm{H}\right), 2.33(\mathrm{~s}, 1 \mathrm{H}), 1.67(\mathrm{~s}, 3 \mathrm{H}) .{ }^{13} \mathrm{C}$ $\operatorname{NMR}\left(\mathrm{CDCl}_{3}\right): \delta 145.1,133.8,133.3,132.4,128.3,128.0,127.6,126.2,125.8,123.7,123.3$, $119.6,73.9,48.4,30.0$.

2-(1-Naphthyl)-4-penten-2-ol (1c) (CAS 745813-65-4)

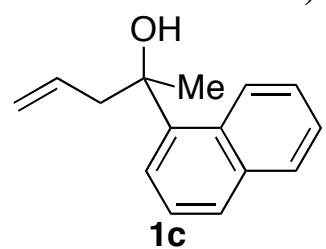

Allylmagnesium bromide $\left(6.5 \mathrm{~mL}, 4.2 \mathrm{mmol}\right.$; $0.65 \mathrm{M}$ solution in $\left.\mathrm{Et}_{2} \mathrm{O}\right)$ was added to a 
solution of 1-acetonaphthone $(337 \mathrm{mg}, 1.98 \mathrm{mmol})$ in $\mathrm{THF}(8.0 \mathrm{~mL})$ at $0{ }^{\circ} \mathrm{C}$ and the mixture was stirred for $5 \mathrm{~h}$ at room temperature. The mixture was quenched with saturated $\mathrm{NH}_{4} \mathrm{Claq}$ and extracted with $\mathrm{Et}_{2} \mathrm{O}$. The organic layer was dried over $\mathrm{MgSO}_{4}$, filterd, and concentrated under vacuum. The residue was chromatographed on silica gel with EtOAc/hexane $=1 / 10$ to afford 1c as a white solid (405 $\mathrm{mg}, 1.91 \mathrm{mmol} ; 96 \%$ yield).

${ }^{1} \mathrm{H} \mathrm{NMR}\left(\mathrm{CDCl}_{3}\right): \delta 8.74\left(\mathrm{~d},{ }^{3} J_{\mathrm{HH}}=8.6 \mathrm{~Hz}, 1 \mathrm{H}\right), 7.87\left(\mathrm{dd},{ }^{3} J_{\mathrm{HH}}=7.8 \mathrm{~Hz}\right.$ and ${ }^{4} J_{\mathrm{HH}}=1.5$ $\mathrm{Hz}, 1 \mathrm{H}), 7.77\left(\mathrm{~d},{ }^{3} J_{\mathrm{HH}}=8.2 \mathrm{~Hz}, 1 \mathrm{H}\right), 7.59\left(\mathrm{dd},{ }^{3} J_{\mathrm{HH}}=7.3 \mathrm{~Hz}\right.$ and $\left.{ }^{4} J_{\mathrm{HH}}=1.1 \mathrm{~Hz}, 1 \mathrm{H}\right), 7.50$ $\left(\mathrm{ddd},{ }^{3} J_{\mathrm{HH}}=8.5\right.$ and $6.8 \mathrm{~Hz}$ and $\left.{ }^{4} J_{\mathrm{HH}}=1.7 \mathrm{~Hz}, 1 \mathrm{H}\right), 7.46\left(\mathrm{td},{ }^{3} J_{\mathrm{HH}}=7.3 \mathrm{~Hz}\right.$ and ${ }^{4} J_{\mathrm{HH}}=1.3 \mathrm{~Hz}$, $1 \mathrm{H}), 7.41\left(\mathrm{t},{ }^{3} J_{\mathrm{HH}}=7.7 \mathrm{~Hz}, 1 \mathrm{H}\right), 5.67\left(\mathrm{dddd},{ }^{3} J_{\mathrm{HH}}=16.9,10.1,7.9\right.$, and $\left.6.8 \mathrm{~Hz}, 1 \mathrm{H}\right), 5.17-$ $5.09(\mathrm{~m}, 2 \mathrm{H}), 3.12\left(\mathrm{dd},{ }^{2} J_{\mathrm{HH}}=13.9 \mathrm{~Hz}\right.$ and $\left.{ }^{3} J_{\mathrm{HH}}=6.7 \mathrm{~Hz}, 1 \mathrm{H}\right), 2.83\left(\mathrm{dd},{ }^{2} J_{\mathrm{HH}}=13.9 \mathrm{~Hz}\right.$ and $\left.{ }^{3} J_{\mathrm{HH}}=7.9 \mathrm{~Hz}, 1 \mathrm{H}\right), 2.26(\mathrm{~s}, 1 \mathrm{H}), 1.83(\mathrm{~s}, 3 \mathrm{H}) .{ }^{13} \mathrm{C} \mathrm{NMR}\left(\mathrm{CDCl}_{3}\right): \delta 142.3,135.0,134.0$, $130.9,129.3,128.7,126.9,125.4,125.2,124.9,123.8,119.3,75.3,47.3,29.7$.

\section{2,2,3-Trimethyl-5-hexen-3-ol (1d) (CAS 1185-08-6)}

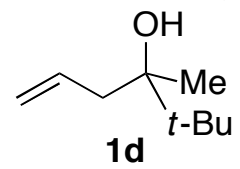

Allylmagnesium bromide $\left(5.6 \mathrm{~mL}, 4.0 \mathrm{mmol} ; 0.71 \mathrm{M}\right.$ solution in $\left.\mathrm{Et}_{2} \mathrm{O}\right)$ was added to a solution of pinacolone $(201 \mathrm{mg}, 2.01 \mathrm{mmol})$ in THF $(10 \mathrm{~mL})$ at $0{ }^{\circ} \mathrm{C}$ and the mixture was stirred for $3 \mathrm{~h}$ at room temperature. The mixture was quenched with saturated $\mathrm{NH}_{4} \mathrm{Claq}$ and extracted with $\mathrm{Et}_{2} \mathrm{O}$. The organic layer was dried over $\mathrm{MgSO}_{4}$, filterd, and concentrated under vacuum. The residue was chromatographed on silica gel with EtOAc/hexane $=1 / 10$ to afford 1d as a colorless oil (177 $\mathrm{mg}, 1.24 \mathrm{mmol} ; 62 \%$ yield).

${ }^{1} \mathrm{H} \mathrm{NMR}\left(\mathrm{CDCl}_{3}\right): \delta 5.95\left(\mathrm{ddt},{ }^{3} J_{\mathrm{HH}}=17.5,10.1\right.$, and $\left.7.4 \mathrm{~Hz}, 1 \mathrm{H}\right), 5.16\left(\mathrm{ddt},{ }^{3} J_{\mathrm{HH}}=10.1\right.$ $\mathrm{Hz},{ }^{2} J_{\mathrm{HH}}=2.0 \mathrm{~Hz}$, and $\left.{ }^{4} J_{\mathrm{HH}}=1.0 \mathrm{~Hz}, 1 \mathrm{H}\right), 5.10\left(\mathrm{ddt},{ }^{3} J_{\mathrm{HH}}=17.0 \mathrm{~Hz},{ }^{2} J_{\mathrm{HH}}=2.0 \mathrm{~Hz}\right.$, and ${ }^{4} J_{\mathrm{HH}}$ $=1.0 \mathrm{~Hz}, 1 \mathrm{H}), 2.35\left(\mathrm{dd},{ }^{2} J_{\mathrm{HH}}=13.7 \mathrm{~Hz}\right.$ and $\left.{ }^{3} J_{\mathrm{HH}}=7.3 \mathrm{~Hz}, 1 \mathrm{H}\right), 2.20\left(\mathrm{ddt},{ }^{2} J_{\mathrm{HH}}=13.7 \mathrm{~Hz}\right.$, ${ }^{3} J_{\mathrm{HH}}=7.4 \mathrm{~Hz}$, and $\left.{ }^{4} J_{\mathrm{HH}}=1.0 \mathrm{~Hz}, 1 \mathrm{H}\right), 1.34(\mathrm{~s}, 1 \mathrm{H}), 1.12(\mathrm{~s}, 3 \mathrm{H}), 0.96(\mathrm{~s}, 9 \mathrm{H}),{ }^{13} \mathrm{C} \mathrm{NMR}$ $\left(\mathrm{CDCl}_{3}\right): \delta 135.3,118.6,75.8,41.1,37.9,25.5,21.8$.

\section{1-Allyl-1,2,3,4-tetrahydronaphthalen-1-ol (1e) (CAS 81336-10-9)}

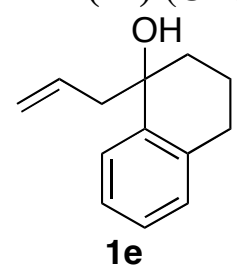

Allylmagnesium bromide $\left(5.6 \mathrm{~mL}, 4.0 \mathrm{mmol} ; 0.71 \mathrm{M}\right.$ solution in $\left.\mathrm{Et}_{2} \mathrm{O}\right)$ was added to a solution of 1-tetralone $(289 \mathrm{mg}, 1.98 \mathrm{mmol})$ in $\mathrm{THF}(8.0 \mathrm{~mL})$ at $0{ }^{\circ} \mathrm{C}$ and the mixture was stirred for $4 \mathrm{~h}$ at room temperature. The mixture was quenched with saturated $\mathrm{NH}_{4} \mathrm{Claq}$ and extracted with $\mathrm{Et}_{2} \mathrm{O}$. The organic layer was dried over $\mathrm{MgSO}_{4}$, filterd, and concentrated under vacuum. The residue was chromatographed on silica gel with EtOAc/hexane $=1 / 10$ to afford 1e as a white solid (219 $\mathrm{mg}, 1.16 \mathrm{mmol} ; 59 \%$ yield).

${ }^{1} \mathrm{H} \mathrm{NMR}\left(\mathrm{CDCl}_{3}\right): \delta 7.55\left(\mathrm{~d},{ }^{3} J_{\mathrm{HH}}=7.5 \mathrm{~Hz}, 1 \mathrm{H}\right), 7.21\left(\mathrm{td},{ }^{3} J_{\mathrm{HH}}=7.5 \mathrm{~Hz}\right.$ and ${ }^{4} J_{\mathrm{HH}}=0.8$ $\mathrm{Hz}, 1 \mathrm{H}), 7.17\left(\mathrm{td},{ }^{3} J_{\mathrm{HH}}=7.4 \mathrm{~Hz}\right.$ and $\left.{ }^{4} J_{\mathrm{HH}}=1.3 \mathrm{~Hz}, 1 \mathrm{H}\right), 7.08\left(\mathrm{~d},{ }^{3} J_{\mathrm{HH}}=7.5 \mathrm{~Hz}, 1 \mathrm{H}\right), 5.81$ $\left(\mathrm{dddd},{ }^{3} J_{\mathrm{HH}}=14.8,12.6,9.5\right.$, and $\left.7.3 \mathrm{~Hz}, 1 \mathrm{H}\right), 5.13\left(\mathrm{~d},{ }^{3} J_{\mathrm{HH}}=15.5 \mathrm{~Hz}, 1 \mathrm{H}\right), 5.13\left(\mathrm{~d},{ }^{3} J_{\mathrm{HH}}=\right.$ $12.0 \mathrm{~Hz}, 1 \mathrm{H}), 2.81\left(\mathrm{dt},{ }^{2} J_{\mathrm{HH}}=16.6 \mathrm{~Hz}\right.$ and $\left.{ }^{3} J_{\mathrm{HH}}=6.5 \mathrm{~Hz}, 1 \mathrm{H}\right), 2.74\left(\mathrm{dt},{ }^{2} J_{\mathrm{HH}}=16.7 \mathrm{~Hz}\right.$ and $\left.{ }^{3} J_{\mathrm{HH}}=5.8 \mathrm{~Hz}, 1 \mathrm{H}\right), 2.65-2.57(\mathrm{~m}, 2 \mathrm{H}), 2.07-2.02(\mathrm{~m}, 1 \mathrm{H}), 1.91(\mathrm{~s}, 1 \mathrm{H}), 1.93-1.78(\mathrm{~m}, 3 \mathrm{H})$. ${ }^{13} \mathrm{C} \mathrm{NMR}\left(\mathrm{CDCl}_{3}\right): \delta 142.0,136.9,134.2,129.0,127.2,126.5,126.3,118.7,72.0,47.1,36.2$, 
$29.9,19.8$.

(E)-1-Phenyl-2-penten-1-one (CAS 61752-66-7)<smiles>C/C=C/C(=O)c1ccccc1</smiles>

Phenyllithium ( $8.33 \mathrm{~mL}, 9.00 \mathrm{mmol} ; 1.08 \mathrm{M}$ solution in cyclohexane/ $\mathrm{Et}_{2} \mathrm{O}$ ) was added to a solution of $(E)$-2-pentenal $(666 \mathrm{mg}, 7.92 \mathrm{mmol})$ in THF $(10 \mathrm{~mL})$ at $0{ }^{\circ} \mathrm{C}$, and the mixture was stirred for $3 \mathrm{~h}$ at room temperature. The reaction was quenched with saturated $\mathrm{NH}_{4} \mathrm{Claq}$ and extracted with $\mathrm{Et}_{2} \mathrm{O}$. The organic layer was dried over $\mathrm{MgSO}_{4}$, filtered, and concentrated under vacuum. The resulting oil was dissolved in $\mathrm{Et}_{2} \mathrm{O}(30 \mathrm{~mL})$ and $\mathrm{MnO}_{2}(7.00 \mathrm{~g}, 80.5$ mmol) was added to it. After stirring for $24 \mathrm{~h}$ at room temperature, the reaction mixture was filtered through celite with $\mathrm{Et}_{2} \mathrm{O}$ and the solvent was removed under vacuum. The residue was chromatographed on silica gel with EtOAc/hexane $=1 / 10$ to afford $(E)$-1-phenyl-2penten-1-one as a colorless oil (782 $\mathrm{mg}, 4.88 \mathrm{mmol} ; 62 \%$ yield).

${ }^{1} \mathrm{H} \mathrm{NMR}\left(\mathrm{CDCl}_{3}\right): \delta 7.95-7.91(\mathrm{~m}, 2 \mathrm{H}), 7.55\left(\mathrm{tt},{ }^{3} J_{\mathrm{HH}}=7.2 \mathrm{~Hz}\right.$ and $\left.{ }^{4} J_{\mathrm{HH}}=1.2 \mathrm{~Hz}, 1 \mathrm{H}\right)$, $7.46\left(\mathrm{t},{ }^{3} J_{\mathrm{HH}}=7.4 \mathrm{~Hz}, 2 \mathrm{H}\right), 7.11\left(\mathrm{dt},{ }^{3} J_{\mathrm{HH}}=15.2\right.$ and $\left.6.4 \mathrm{~Hz}, 1 \mathrm{H}\right), 6.87\left(\mathrm{dt},{ }^{3} J_{\mathrm{HH}}=15.6 \mathrm{~Hz}\right.$ and $\left.{ }^{4} J_{\mathrm{HH}}=1.6 \mathrm{~Hz}, 1 \mathrm{H}\right), 2.35$ (quint of $\mathrm{d},{ }^{3} J_{\mathrm{HH}}=7.1 \mathrm{~Hz}$ and $\left.{ }^{4} J_{\mathrm{HH}}=1.6 \mathrm{~Hz}, 2 \mathrm{H}\right), 1.14\left(\mathrm{t},{ }^{3} J_{\mathrm{HH}}=7.4\right.$ $\mathrm{Hz}, 3 \mathrm{H})$.

\section{(E)-4-Phenyl-1,5-octadien-4-ol (1f)}

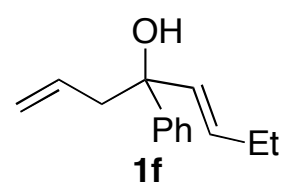

Allylmagnesium bromide $\left(5.6 \mathrm{~mL}, 4.0 \mathrm{mmol} ; 0.71 \mathrm{M}\right.$ solution in $\mathrm{Et}_{2} \mathrm{O}$ ) was added to a solution of (E)-1-phenyl-2-penten-1-one $(322 \mathrm{mg}, 2.01 \mathrm{mmol})$ in THF $(10 \mathrm{~mL})$ at $0{ }^{\circ} \mathrm{C}$ and the mixture was stirred for $3 \mathrm{~h}$ at room temperature. The mixture was quenched with saturated $\mathrm{NH}_{4} \mathrm{Claq}$ and extracted with $\mathrm{Et}_{2} \mathrm{O}$. The organic layer was dried over $\mathrm{MgSO}_{4}$, filterd, and concentrated under vacuum. The residue was chromatographed on silica gel with EtOAc/hexane $=1 / 10$ to afford $\mathbf{1 f}$ as a colorless oil $(381 \mathrm{mg}, 1.88 \mathrm{mmol} ; 94 \%$ yield).

${ }^{1} \mathrm{H} \mathrm{NMR}\left(\mathrm{CDCl}_{3}\right): \delta 7.44\left(\mathrm{~d},{ }^{3} J_{\mathrm{HH}}=7.3 \mathrm{~Hz}, 2 \mathrm{H}\right), 7.33\left(\mathrm{t},{ }^{3} J_{\mathrm{HH}}=7.6 \mathrm{~Hz}, 2 \mathrm{H}\right), 7.23\left(\mathrm{tt},{ }^{3} J_{\mathrm{HH}}\right.$ $=7.3 \mathrm{~Hz}$ and $\left.{ }^{4} J_{\mathrm{HH}}=1.0 \mathrm{~Hz}, 1 \mathrm{H}\right), 5.78\left(\mathrm{dt},{ }^{3} J_{\mathrm{HH}}=15.6 \mathrm{~Hz}\right.$ and $\left.{ }^{4} J_{\mathrm{HH}}=0.9 \mathrm{~Hz}, 1 \mathrm{H}\right), 5.70(\mathrm{dt}$, ${ }^{3} J_{\mathrm{HH}}=15.5$ and $\left.5.9 \mathrm{~Hz}, 1 \mathrm{H}\right), 5.66\left(\mathrm{ddt},{ }^{3} J_{\mathrm{HH}}=17.3,10.1\right.$, and $\left.7.3 \mathrm{~Hz}, 1 \mathrm{H}\right), 5.16-5.11(\mathrm{~m}, 2 \mathrm{H})$, $2.71\left(\mathrm{dd},{ }^{2} J_{\mathrm{HH}}=13.8 \mathrm{~Hz}\right.$ and $\left.{ }^{3} J_{\mathrm{HH}}=7.1 \mathrm{~Hz}, 1 \mathrm{H}\right), 2.64\left(\mathrm{dd},{ }^{2} J_{\mathrm{HH}}=13.8 \mathrm{~Hz}\right.$ and ${ }^{3} J_{\mathrm{HH}}=7.5 \mathrm{~Hz}$, $1 \mathrm{H}), 2.15(\mathrm{~s}, 1 \mathrm{H}), 2.10-2.04(\mathrm{~m}, 2 \mathrm{H}), 0.99\left(\mathrm{t},{ }^{3} J_{\mathrm{HH}}=7.4 \mathrm{~Hz}, 3 \mathrm{H}\right) .{ }^{13} \mathrm{C} \mathrm{NMR}\left(\mathrm{CDCl}_{3}\right): \delta 146.0$, 134.8, 133.6, 131.4, 128.2, 126.8, 125.6, 119.7, 75.5, 47.3, 25.4, 13.7. Anal. Calcd for $\mathrm{C}_{14} \mathrm{H}_{18} \mathrm{O}: \mathrm{C}, 83.12 ; \mathrm{H}, 8.97$. Found: $\mathrm{C}, 83.13 ; \mathrm{H}, 8.83$.

\section{Catalytic Reactions}

\section{General Procedure for Table 2.}

A solution of $[\mathrm{Rh}(\mathrm{OH})(\mathrm{cod})]_{2}(4.6 \mathrm{mg}, 20 \mu \mathrm{mol} \mathrm{Rh})$ and $(R)-\mathrm{H}_{8}$-binap (13.9 mg, 22.0 $\mu \mathrm{mol})$ in toluene $(1.0 \mathrm{~mL})$ was stirred for $10 \mathrm{~min}$ at $80{ }^{\circ} \mathrm{C}$. Alcohol $( \pm)-\mathbf{1}(0.4 \mathrm{mmol})$ was added to it with additional toluene $(1.0 \mathrm{~mL})$ and the resulting mixture was refluxed for $5-17 \mathrm{~h}$ at $120^{\circ} \mathrm{C}$. After cooled to room temperature, this was passed through a pad of silica gel with $\mathrm{Et}_{2} \mathrm{O}$, and the solvent was removed under vacuum. The residue was purified by silica gel 
preparative TLC with EtOAc/hexane to afford resolved 1.

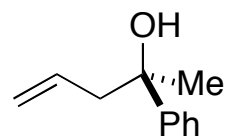

(R)-1a

Entry 1. The reaction was conducted for $9 \mathrm{~h}$ to give $67 \%$ conversion. The ee was determined on a Daicel Chiralcel OJ-H column with hexane $/ 2$-propanol $=100 / 1$, flow $=0.5 \mathrm{~mL} / \mathrm{min}$. Retention times: 26.6 min $\left[(R)\right.$-enantiomer], $35.6 \min \left[(S)\right.$-enantiomer]. $89 \%$ ee. $[\alpha]^{20}{ }_{\mathrm{D}}+57.9$ (c $0.80, \mathrm{CHCl}_{3}$ ). The absolute configuration was determined by comparison of the optical rotation with that reported in the literature. ${ }^{8}$

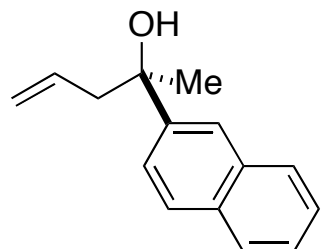

(R)-1b

Entry 2. The reaction was conducted for $9 \mathrm{~h}$ to give $68 \%$ conversion. The ee was determined on a Daicel Chiralcel OD-H column with hexane $/ 2$-propanol $=95 / 5$, flow $=0.5 \mathrm{~mL} / \mathrm{min}$. Retention times: 25.6 min $\left[(S)\right.$-enantiomer], 32.9 min $\left[(R)\right.$-enantiomer]. $88 \%$ ee. $[\alpha]^{20}+57.8$ $\left(c 1.10, \mathrm{CHCl}_{3}\right)$. The absolute configuration was assigned by analogy with entry 1 .

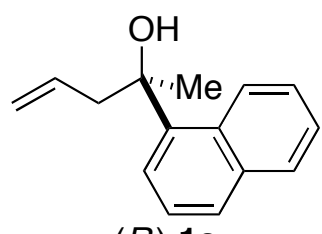

(R)-1c

Entry 3. The reaction was conducted for $9 \mathrm{~h}$ to give $67 \%$ conversion. The ee was determined on a Daicel Chiralcel OJ-H column with hexane $/ 2$-propanol $=95 / 5$, flow $=0.5 \mathrm{~mL} / \mathrm{min}$. Retention times: 28.7 min [ $(R)$-enantiomer], 31.0 min $\left[(S)\right.$-enantiomer]. $94 \%$ ee. $[\alpha]^{20}{ }_{\mathrm{D}}+11.5$ $\left(c 1.01, \mathrm{CHCl}_{3}\right)$. The absolute configuration was assigned by analogy with entry 1 .

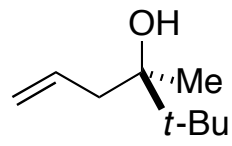

(R)-1d

Entry 5. The reaction was conducted on a $1.0 \mathrm{mmol}$ scale for $9 \mathrm{~h}$ to give $70 \%$ conversion. For ee analysis, the resolved alcohol was derivatized to its 4-methoxybenzyl ether (S1). $[\alpha]^{20}+14.4\left(c 0.97, \mathrm{CHCl}_{3}\right)$. The absolute configuration was assigned by analogy with entry 1.<smiles>C=CCC(C)(C)OCc1ccc(OC)cc1</smiles>

(R)-S1

4-Methoxybenzyl-2,2,2-trichloroethanimidate (43.4 $\mathrm{mg}, 0.154 \mathrm{mmol})$ and $\mathrm{Sc}(\mathrm{OTf})_{3}(0.90$ $\mathrm{mg}, 1.8 \mu \mathrm{mol})$ were added to a solution of resoved $1 \mathbf{d}(13.5 \mathrm{mg}, 94.9 \mu \mathrm{mol})$ in toluene $(5.0$

\footnotetext{
${ }^{8}$ Soai, K.; Ishizaki, M.; Yokoyama, S. Chem. Lett. 1987, 341.
} 
$\mathrm{mL}$ ) at room temperature and the mixture was stirred for $5 \mathrm{~min}$. The reaction was quenched with saturated $\mathrm{NaHCO}_{3} a q$ and extracted with EtOAc. The organic layer was dried over $\mathrm{MgSO}_{4}$, filterd, and concentrated under vacuum. The residue was purified by silica gel preparative TLC with EtOAc/hexane $=1 / 10$ and then with $\mathrm{CH}_{2} \mathrm{Cl}_{2} /$ hexane $=1 / 1$ to afford $\mathbf{S 1}$ as a colorless oil $(9.8 \mathrm{mg}, 37.3 \mu \mathrm{mol} ; 39 \%$ yield). The ee of $\mathbf{S 1}$ was determined on a Daicel Chiralcel OJ-H column with hexane $/ 2$-propanol $=100 / 1$, flow $=0.4 \mathrm{~mL} / \mathrm{min}$. Retention times: $42.7 \min \left[(R)\right.$-enantiomer], $44.8 \min [(S)$-enantiomer $] .84 \%$ ee. $[\alpha]^{20}{ }_{\mathrm{D}}+34.9(c 0.35$, $\left.\mathrm{CHCl}_{3}\right)$.

${ }^{1} \mathrm{H}$ NMR $\left(\mathrm{CDCl}_{3}\right): \delta 7.26\left(\mathrm{~d},{ }^{3} J_{\mathrm{HH}}=8.8 \mathrm{~Hz}, 2 \mathrm{H}\right), 6.86\left(\mathrm{~d},{ }^{3} J_{\mathrm{HH}}=8.7 \mathrm{~Hz}, 2 \mathrm{H}\right), 6.02-5.93$ $(\mathrm{m}, 1 \mathrm{H}), 5.08-5.01(\mathrm{~m}, 2 \mathrm{H}), 4.48\left(\mathrm{~d},{ }^{2} J_{\mathrm{HH}}=11.0 \mathrm{~Hz}, 1 \mathrm{H}\right), 4.43\left(\mathrm{~d},{ }^{2} J_{\mathrm{HH}}=11.0 \mathrm{~Hz}, 1 \mathrm{H}\right), 3.80$ $(\mathrm{s}, 3 \mathrm{H}), 2.53\left(\mathrm{dd},{ }^{2} J_{\mathrm{HH}}=14.5 \mathrm{~Hz}\right.$ and $\left.{ }^{3} J_{\mathrm{HH}}=6.7 \mathrm{~Hz}, 1 \mathrm{H}\right), 2.31\left(\mathrm{ddt},{ }^{2} J_{\mathrm{HH}}=14.6 \mathrm{~Hz},{ }^{3} J_{\mathrm{HH}}=\right.$ $7.6 \mathrm{~Hz}$, and $\left.{ }^{4} J_{\mathrm{HH}}=1.2 \mathrm{~Hz}, 1 \mathrm{H}\right), 1.23(\mathrm{~s}, 3 \mathrm{H}), 0.99(\mathrm{~s}, 9 \mathrm{H}) .{ }^{13} \mathrm{C} \mathrm{NMR}\left(\mathrm{CDCl}_{3}\right): \delta 158.7,136.9$, 132.8, 128.3, 116.5, 113.7, 80.6, 65.1, 55.4, 40.7, 39.5, 26.2, 17.5. Anal. Calcd for $\mathrm{C}_{17} \mathrm{H}_{26} \mathrm{O}_{2}$ : C, 77.82; H, 9.99. Found: C, 77.88; H, 10.25.<smiles>C=CCC1(O)CCCc2cc(I)ccc21</smiles>

Entry 6. The reaction was conducted for $6 \mathrm{~h}$ to give $61 \%$ conversion. The ee was determined on a Daicel Chiralcel OJ-H column with hexane $/ 2$-propanol $=100 / 1$, flow $=0.5 \mathrm{~mL} / \mathrm{min}$. Retention times: $25.9 \mathrm{~min}\left[(R)\right.$-enantiomer], $30.4 \mathrm{~min}\left[(S)\right.$-enantiomer]. $71 \%$ ee. $[\alpha]^{20}{ }_{\mathrm{D}}+24.7$ $\left(c 1.29, \mathrm{CHCl}_{3}\right)$. The absolute configuration was assigned by analogy with entry 1 .

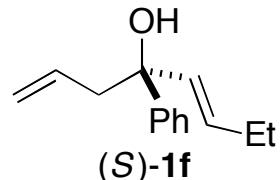

Entry 7. The reaction was conducted for $5 \mathrm{~h}$ to give $67 \%$ conversion. The ee was determined on a Daicel Chiralcel OD-H column with hexane $/ 2$-propanol $=100 / 1$, flow $=0.5 \mathrm{~mL} / \mathrm{min}$. Retention times: $30.1 \mathrm{~min}\left[(S)\right.$-enantiomer], $32.2 \mathrm{~min}\left[(R)\right.$-enantiomer]. $70 \%$ ee. $[\alpha]^{20}{ }_{\mathrm{D}}-1.8$ (c 1.29, $\mathrm{CHCl}_{3}$ ). The absolute configuration was assigned by analogy with entry 1 . 


\section{IV. ${ }^{1} H$ NMR Spectra}

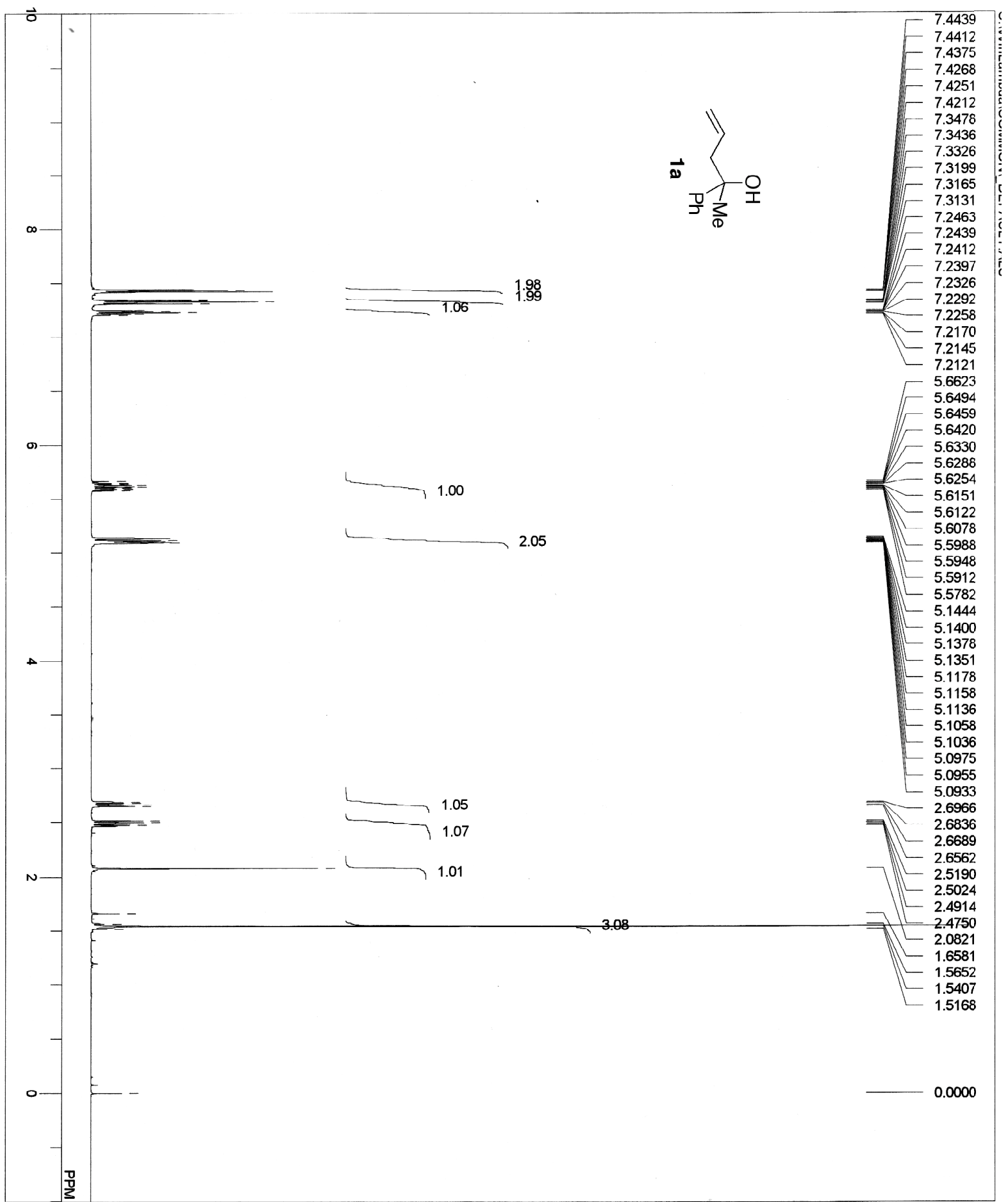

(500 MHz in $\mathrm{CDCl}_{3}$ ) 


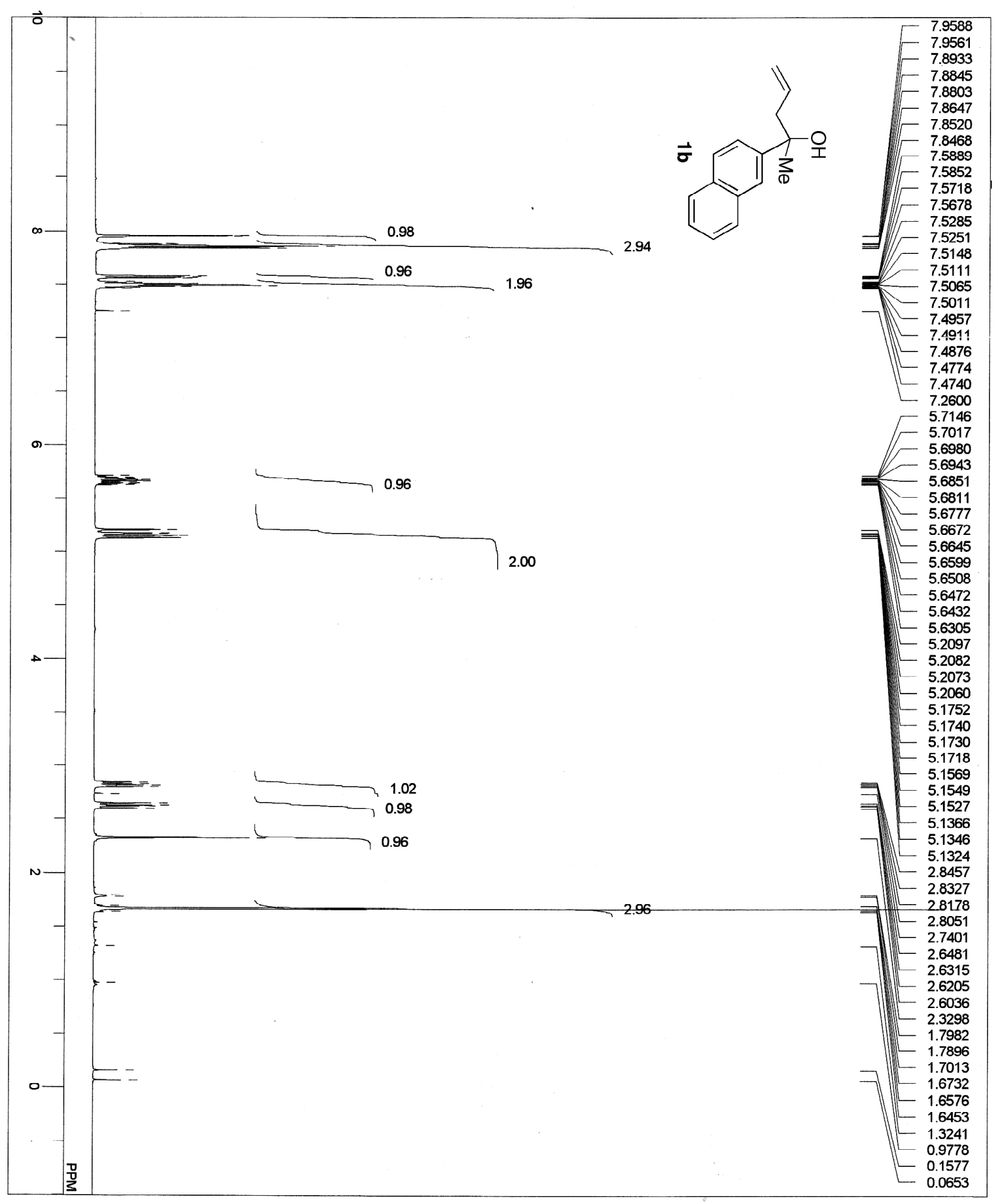

(500 $\mathrm{MHz}$ in $\mathrm{CDCl}_{3}$ ) 


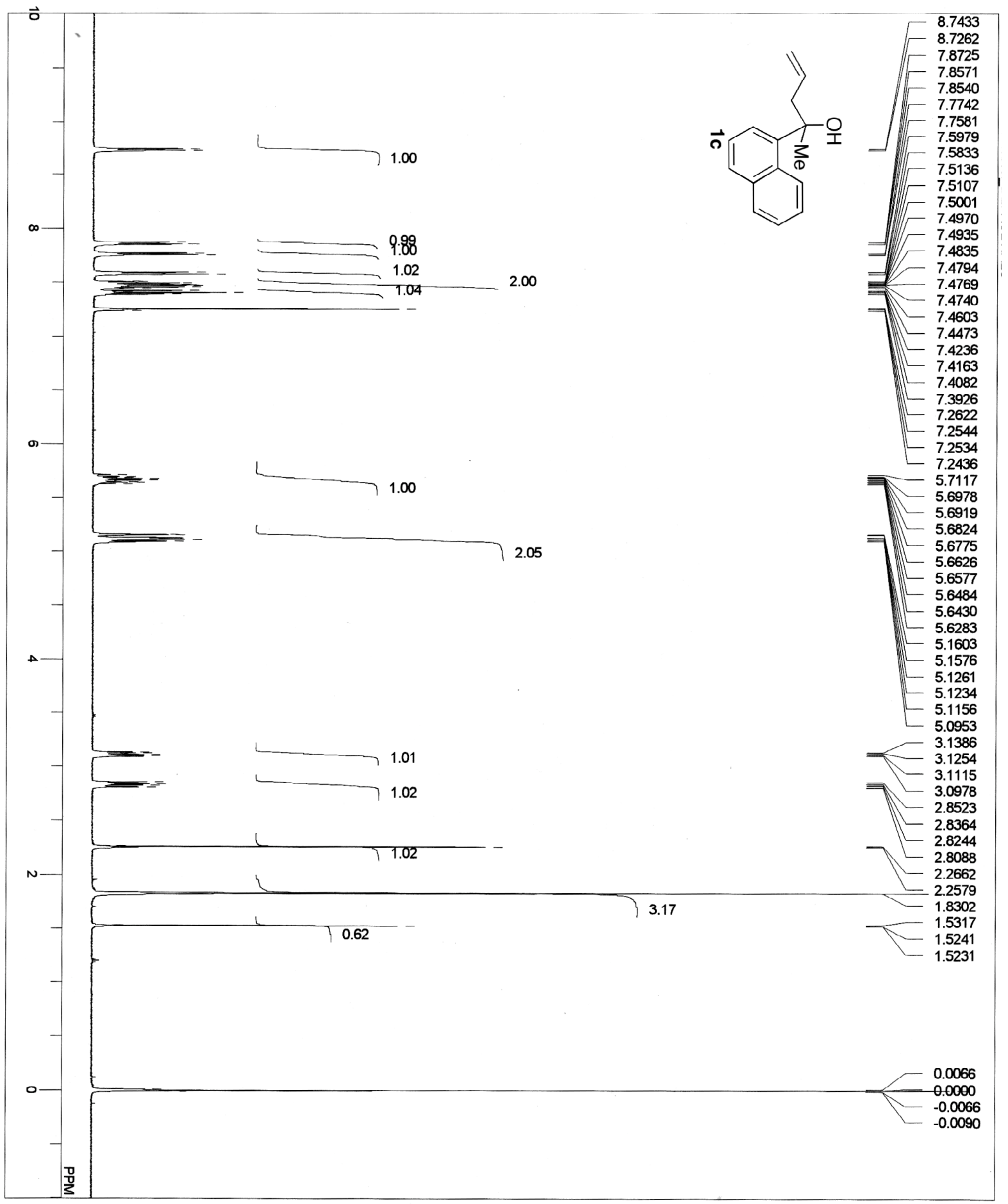

(500 MHz in $\mathrm{CDCl}_{3}$ ) 


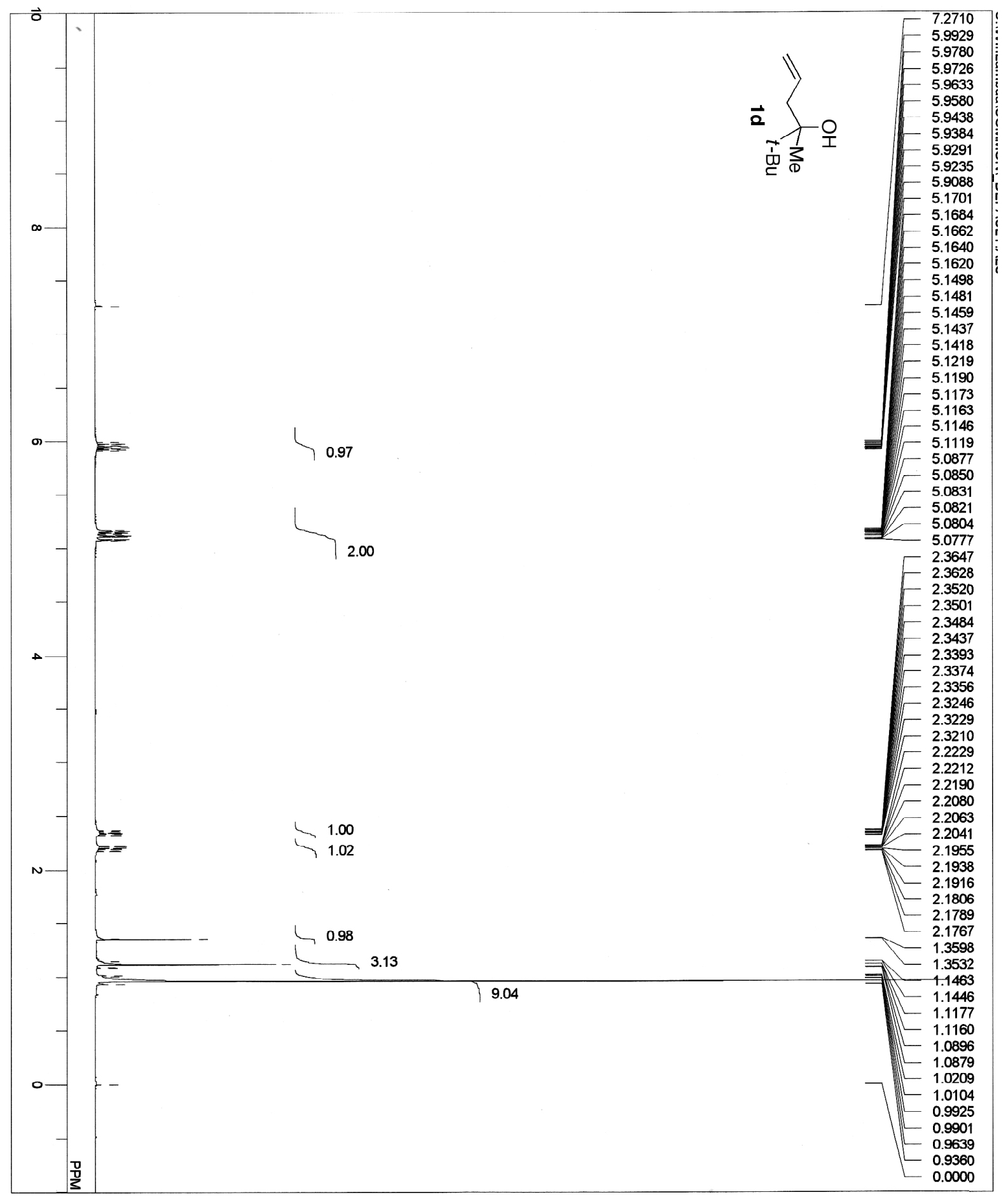

(500 $\mathrm{MHz}$ in $\mathrm{CDCl}_{3}$ ) 


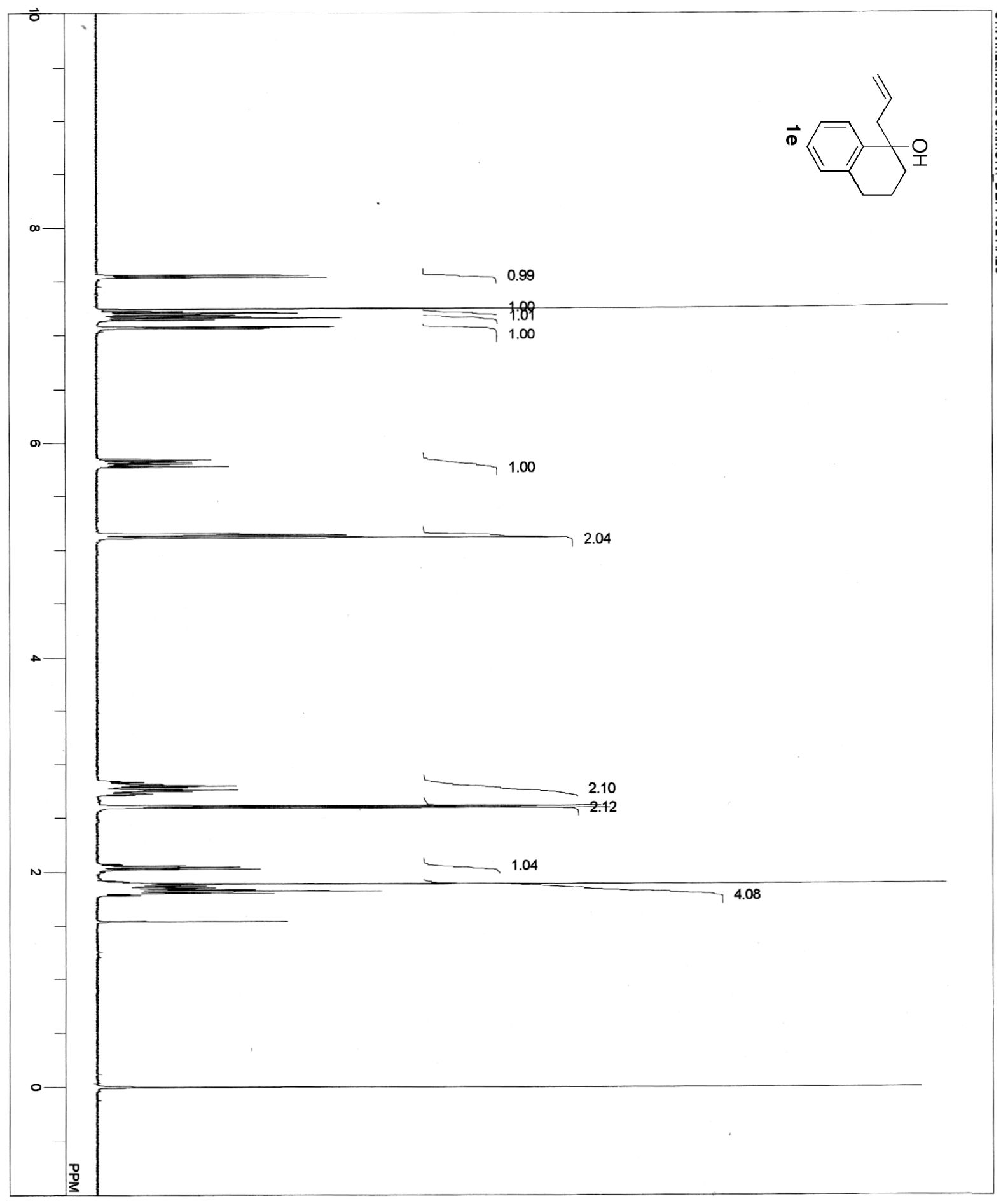

(500 $\mathrm{MHz}$ in $\mathrm{CDCl}_{3}$ ) 


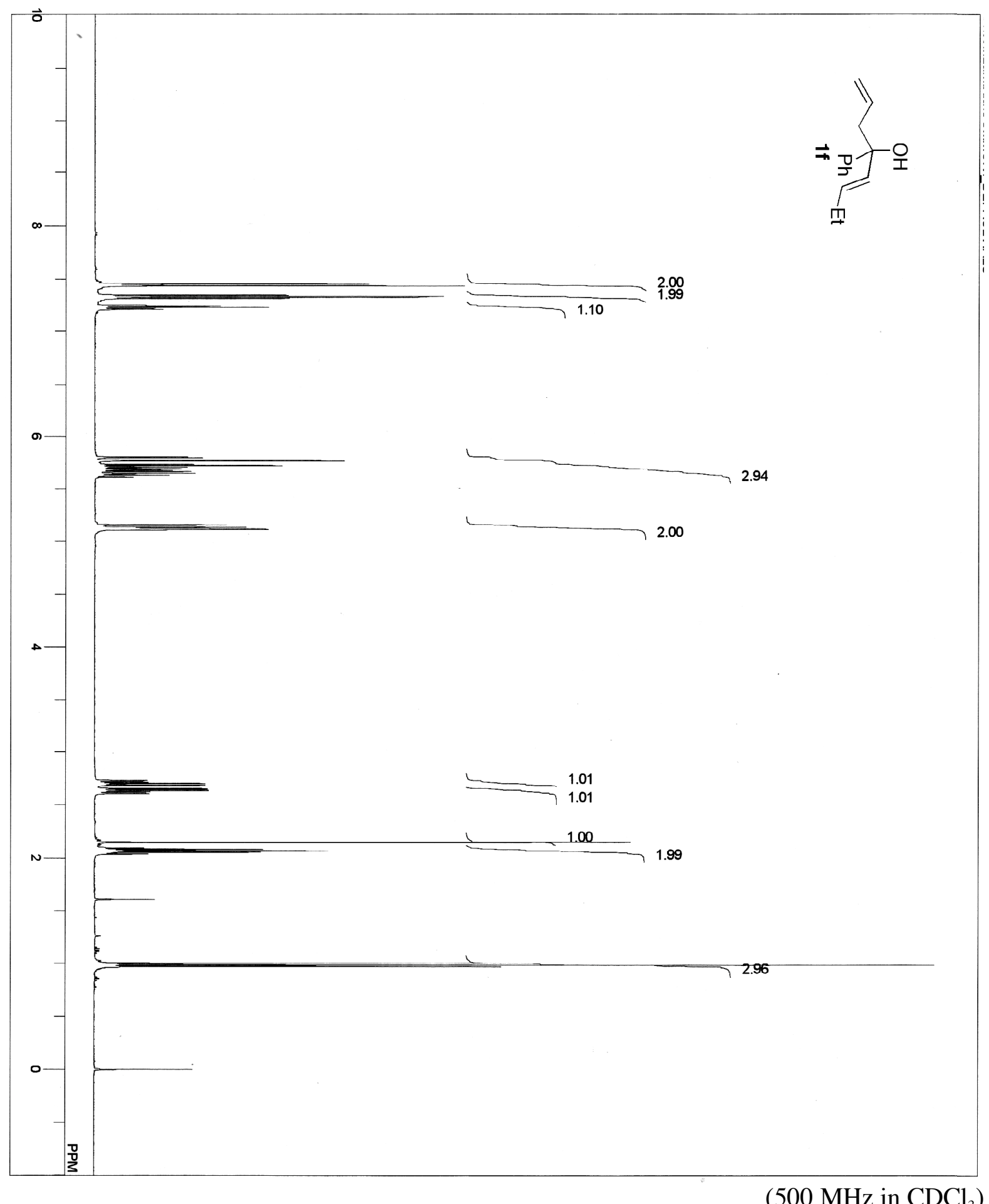

(500 MHz in $\mathrm{CDCl}_{3}$ ) 


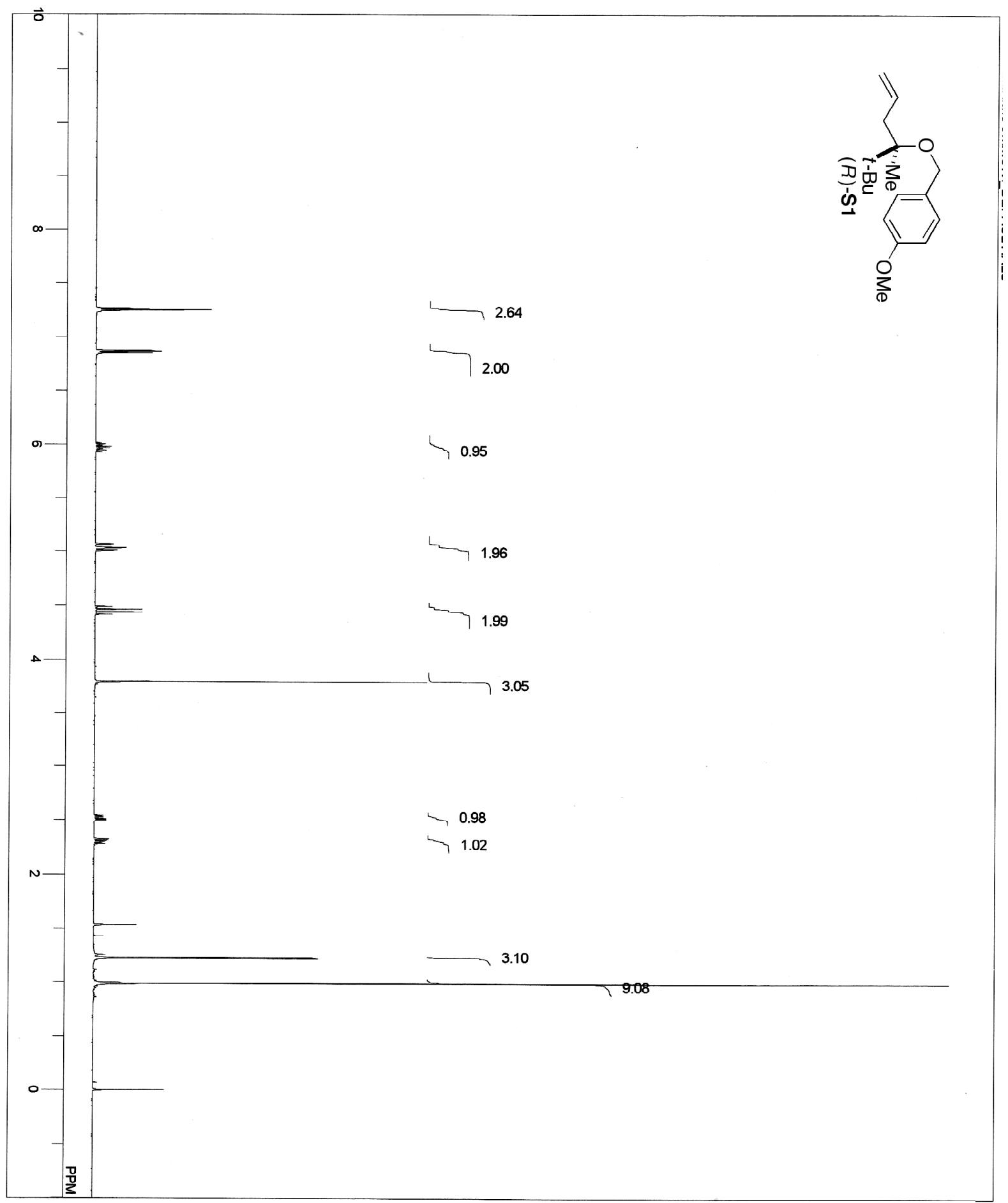

(500 $\mathrm{MHz}$ in $\mathrm{CDCl}_{3}$ ) 